\title{
Innovations
}

\section{Commentary: Open access publishing in healthcare}

\section{Authors}

\section{Mirko von Elstermann ${ }^{1, *}$}

\section{Commentary}

We at Innovations in Global Health Professions Education decided that our periodical would be 'platinum' open access (OA) - free to access and free to publish. Does this mean we are just jumping on the bandwagon in "the unstoppable rise of open access"?

This, by all means, is not the case. We are deeply convinced of the benefits for healthcare from OA the free access to scholarly literature. They are obvious: real time reception of research will improve care. If access depends on journal subscriptions, healthcare professionals from less wealthy countries will be excluded. Moreover, regardless of location, those practitioners (hospital doctors, General Practitioners, nurses and others) who are not affiliated with institutions subscribing to biomedical journals are barred from the most recent research. Even for professionals within academia, it is hard for their institutions to justify paying so much money for journal content that was produced and peerreviewed by them.
Yet, as with every rising innovation, embarking on OA means there is no easy ride. There is the 'green way' of open access in which authors deposit their manuscripts in an institutional repository and publish their work in journals of their choice. A major disadvantage of green $\mathrm{OA}$ is the embargo period: In the health sciences, more than half of the publishers do not allow immediate open access after acceptance of the manuscript, ${ }^{2}$ thus delaying access to the most recent research for six to 24 months. Although a general mandate for green $\mathrm{OA}$ could enforce depositing in repositories and urge shortening of embargo periods, ${ }^{3}$ it is difficult to see why commercial publishers interested in revenues should drop embargos altogether.

The alternative is to submit a manuscript to a journal featuring 'gold' OA, which allows immediate, free online access to the publication. Unfortunately, a good share of gold OA journals ask for publication fees per article (or 'article processing charges', APCs), which authors with less generous funding (see above) may not be able to pay. Thus, the exclusion of readers from access may turn into an exclusion of authors from publishing. Moreover, some argue that charging fees per article gives an incentive to publishers to accept as many articles
${ }^{1}$ Managing Editor of IGHPE, Weill Cornell Medicine-Qatar

* mpe2001@qatar-med.cornell.edu

\section{Cite this article as:}

Elstermann MV. Commentary: Open access publishing in healthcare. Innovations in Global Health Professions Education. 2015:2. http://dx.doi.org/10.20421/ighpe2015.2

This is an open access article distributed under the terms of the Creative Commons Attribution license CC BY 4.0, which permits unrestricted use, distribution and reproduction in any medium, provided the original work is properly cited. 
as possible. So-called 'predatory publishers', ${ }^{4}$ motivated by nothing other than greed for money, publish bad research because editorial services and peer review services are amiss. ${ }^{5}$

However, publishing inferior material is not a specific domain of OA journals. We saw enough examples of questionable practices in traditional subscriptionbased 'toll access' ${ }^{6}$ journals - publishing fraudulent research (because of appealing titles or results ${ }^{8}$ ), publishing ghost-written material as industry propaganda, ${ }^{9}$ or entire 'fake journals' of respected publishers. ${ }^{10}$

The possible exclusion of authors remains the greatest danger of APC-based gold open access. Innovations in healthcare education might be a case in point: They can start with a brief concept for professional training implemented somewhere in the world, below the radar of big funding. The concept may become more and more sophisticated, eventually leading to a measurable improvement of clinical performance. Apart from the fact that its initiators may be people with little time to write down what they did, to require them to pay 1,500 United States Dollars or more for a journal publication, in addition to the sometimes complicated manuscript handling of journals, could very well put an end to their efforts. On the other hand, if they send their results to a 'toll access' journal, they will be shut out from seeing their work published and discussed. Finally, a good concept could be stored away somewhere and never see the light of day.

To be fair, there are many more business models for gold OA worth mentioning. Wealthy funding organizations can cover publication costs entirely as some kind of sponsorship to attract excellent contributions from a specific field (e.g., molecular biology - see www.elifesciences.org). A publication 'lifetime flat rate' can be offered to individual investigators, offering to publish one, two, or an unlimited amount of manuscripts for a one-time fee (e.g., https://peerj.com). Research institutions can acquire memberships in a journal collection of a publisher, leading to much reduced APCs (e.g., www. biomedcentral.com).

These alternative models for gold OA have a common feature: They abolish or reduce APCs. Yet, health innovations may drown in a general scientific or medical journal, and innovators outside of academic institutions can hardly negotiate a contract for a publisher membership. Therefore, creating journals editorially handled by investigators and managed by academicians themselves, using open-source and inexpensive manuscript processing platforms, appears to be the method of choice for starting gold OA specialist journals. It is true that many current gold OA journals waive their APCs for economically weak countries (albeit with varying criteria), but then poor authors from many of the world's middle-income countries are still without funding to publish. Waiving APCs on a case-to-case basis, in turn, has been shown to discourage investigators from submitting their manuscripts."

All in all, it is difficult to pinpoint what justifies the high costs of both subscription- and APC-based commercial journals. ${ }^{12}$ To prevent exclusion of both readers and authors, excellent gold OA journals founded outside of the commercial publisher market should be launched (see, e.g. www.collabra. org); journals based within the academic library system are more and more seen as a viable alternative $^{13}$ to the traditional journal model. Because of their leaner editorial processes, APCs can be low and more countries and reader groups can be exempted from paying fees. Thereby, the economic barriers will decrease for publishing innovative ideas that performed well.

In addition to innovators and leaders in health professions education, clever practitioners who are trying to implement great ideas are spread all over the world. By dropping both publication fees for authors and access fees for readers, we at Innovations in Global Healthcare Professions Education want to provide them with a forum that maximizes its audience to discuss and test new concepts more broadly and quickly. We are sure that choosing the right way in the "unstoppable rise of OA" will help transfer brilliant innovations in healthcare from one place of the world to another to ultimately enhance the distribution and quality of patient care and outcomes.

\section{References}

1. Gruss P. The unstoppable rise of Open Access. Max Planck Res. 2013; 7(4): 6-7. 
2. Laakso M. Green open access policies of scholarly journal publishers: a study of what, when, and where self-archiving is allowed. Scientometrics. 2014; 99: 475-494.

3. Harnad S. Optimizing Open Access Policy. Serials Rev. Epub 2015 September 11. doi: $10.1080 / 0361526$ X.2015.1076368.

4. Berger M, Cirasella J. Beyond Beall's List: better understanding predatory publishers. College \& Research Libraries News. 2015; 76: 132-135.

5. Bohannon J. Who's afraid of peer review? Science. 2013; 342: 60-65.

6. Suber P. Open Access. Cambridge (MA): MIT Press; 2012.

7. UMass Amherst. Cases of Scientific Retraction [Internet]. Amherst MA: UMass Amherst Libraries 2015 [cited 2015 Nov 25]. Available from http://guides.library.umass. edu/content.php?pid=463078\&sid=3863413.

8. Obokata H, Wakayama T, Sasai Y, Kojima $\mathrm{K}$, Vacanti MP, Niwa $\mathrm{H}$, et al. Stimulustriggered fate conversion of somatic cells into pluripotency. Nature. 2014; 505: 641-647. Retraction in: Obokata $\mathrm{H}$, Wakayama T, Sasai Y, Kojima K, Vacanti MP, Niwa H, et al. Nature. 2014; 511: 112.

9. Singer N. Medical papers by ghostwriters pushed therapy. The New York Times. 2009 Aug 4 [cited 2015 Sept 16]. Available from http://www.nytimes.com/2009/08/05/health/ research/05ghost.html

10. Grant P. Elsevier published 6 fake journals. The Scientist. 2009 Sept 7 [cited 2015 Sept 16]. Available from: http://www.the-scientist. com/?articles.view/articleNo/27383/title/ Elsevier-published-6-fake-journals

11. Peterson AT, Emmett A, Greenberg ML. Open Access and the author-pays problem: assuring access for readers and authors in a global community of scholars. Journal of
Librarianship and Scholarly Communication. 2013; 1(3): eP1064.

12. Conley JP, Wooders M. But what have you done for me lately? Commercial publishing, scholarly communication, and Open-Access. Economic Analysis \& Policy. 2009; 39: 71-87

13. Jones P. What's going on in the library? Part 1 : librarian publishers may be more important than you think. 2014 Dec 1 [cited 2015 Sept 16]. In: The Scholarly Kitchen [Internet]. Wheat Ridge (CO): Society for Scholarly Publishing. c2014. Available from: http://scholarlykitchen. sspnet.org/2014/12/01/whats-going-on-in-thelibrary-part-1-librarian-publishers-may-bemore-important-than-you-think 